\title{
ZAJEM PODATKOV ZA GRAFIČNI DEL BAZE PODATKOV V GIS-ih
}

\author{
Zmago Fras
}

\section{Izvleček}

UDK 528:91:681.3

Zajem podatkov je najobsežnejša naloga pri uvajanju GIS-a v določeno okolje. Ker je cenouno najuečja postavka, je potrebno zelo dobro preučiti katere podatke potrebujemo, kje jih lahko dobimo in na kakšen način jih lahko pretvorimo $v$ obliko razumljivo GIS orodjem. Tematika zajema podatkov je $v$ prispevku obdelana iz teoretičnega in praktičnega vidika. Pri slednjem je dan povdarek postopkom zajema izvedenih podatkov in digitalnem ortofotu kot možnem osnovnem informacijskem sloju $v$ GIS.

UDC 528:91:681.3

\section{Abstract}

DATA ACQUISITION FOR THE GRAPHIC PART OF GIS DATA BASE

Data acquisition is the most extensive task in introducing GIS in a certain environment. As regards prices it is the greatest item, so it is neccessary to study well which data are needed, where data can be found and in a which way they can be converted into a proper form understood to GIS tools. Themes of data acquisiton are in the paper elaborated from both theorethical and practical aspects. In practical aspects, emphasize to procedures of derived data acquisition and to digital orthophoto as a possible basic cover in GIS, is given.

\section{UVOD}

Najvažnejši sestavni del geoinformacijskih sistemov so podatki, natančneje rečeno digitalni podatki, ki so osnova za analize in ocene stanja $\mathrm{v}$ prostoru s pomočjo računalnika. Zato je zajemanje podatkov $v$ digitalni obliki odločilna osnova za uporabo in uspeh določenega GIS-a.

Podatkovne baze, ki služijo kot osnova za "življenje" takšnih informacijskih sistemov morajo zadovoljiti visoke zahteve glede natančnosti, popolnosti in strukture. Te zahteve pogojujejo, da je zajem podatkov o prostoru v digitalni obliki delovno intenzivna dejavnost, ki zahteva veliko časa in denarja.

Mag. Zmago FRAS, Tržaška 49, 61000 Ljubljana 
Podatke o prostoru, ki jih zajemamo $\mathrm{v}$ digitalno obliko ločimo $\mathrm{v}$ dve glavni skupini:

- geometrični podatki vključno s topološkimi informacijami,

- pisni, tematski podatki.

Izbira metode zajemanja je $\mathrm{v}$ glavnem odvisna od uporabe in "objekta" za katerega oz. iz katerega zajemamo podatke. Robna pogoja, ne pa tudi nepomembna, pri izbiri metode zajemanja podatkov sta:

- razpoložljiva denarna sredstva,

- zahtevana funkcionalnost GIS-a.

Splošno velja, da se ob velikem številu možnih informacij, ki so delno že v digitalni obliki, odsvetuje zajemanje osnovnih podatkov, če so obstoječi izvedeni kakorkoli še uporabni.

V fazi zajemanja podatkov moramo najti takšno rešitev, ki bo $\mathrm{v}$ največji meri dala pozitvne odgovore na vprašanja, ki se nanašajo na:

- natančnost, tako geometrično kot tematsko,

- pravilnost, popolnost, pravno veljavnost podatkov,

- aktualnost,

- obseg dela pri zajemanju podatkov.

Tabela 1: Grobe značilnosti najpomembnejših metod za zajemanje.

\begin{tabular}{|c|c|c|c|c|}
\hline Netoda & $\begin{array}{l}\text { Osnovi } \\
\text { element }\end{array}$ & Natançnost & $\begin{array}{l}\text { Primernost } \\
\text { za področia }\end{array}$ & Obseg dela \\
\hline $\begin{array}{l}\text { Izmera } \\
\text { tahimetrija } \\
\text { ortogonalna } \\
\text { izmera }\end{array}$ & $n$ & $\begin{array}{l}\mathrm{cm} \cdot \mathrm{dm} \\
\mathrm{cm} \cdot \mathrm{dm}\end{array}$ & $\begin{array}{l}\text { lok. } \\
\text { lok. }\end{array}$ & $\begin{array}{l}\text { srednji } \\
\text { majhen }\end{array}$ \\
\hline $\begin{array}{l}\text { Fotogrametrija } \\
\text { stereo } \\
\text { DMR (višine) } \\
\text { interpretacija } \\
\text { satelitski } \\
\text { posnetki }\end{array}$ & $\begin{array}{l}4 \\
4 \\
p \\
p\end{array}$ & $\begin{array}{c}1 \cdot 10^{-5} \cdot \mathrm{mb}_{\mathrm{b}} \\
1 \cdot 10^{-4} \cdot \mathrm{h}_{\mathrm{g}} \\
>10 \mathrm{~m}\end{array}$ & $\begin{array}{l}\text { lok.-reg. } \\
\text { lok.-reg. } \\
\text { lok.-reg. } \\
\text { reg.-ciob. }\end{array}$ & $\begin{array}{l}\text { velik } \\
\text { velik } \\
\text { majhen } \\
\text { veliik }\end{array}$ \\
\hline $\begin{array}{l}\text { Digitalizacija } \\
\text { točna } \\
\text { pol -avtomatska } \\
\text { avtomatska }\end{array}$ & $\begin{array}{l}t \\
t 1 \\
t \cdot p\end{array}$ & $\begin{array}{l}2.5^{*} 10^{-4} \cdot \mathrm{m}_{\mathrm{k}} \\
2.5^{*} 10^{-4} \cdot \mathrm{m}_{\mathrm{k}} \\
2.5^{*} 10^{-4} \cdot \mathrm{m}_{\mathrm{k}}\end{array}$ & $\begin{array}{l}\text { lok.-glob. } \\
\text { lok.-glob. } \\
\text { lok.-glob. }\end{array}$ & $\begin{array}{l}\text { srednji } \\
\text { velik } \\
\text { veliik }\end{array}$ \\
\hline
\end{tabular}

t ... točka, 1 ... linija, $\quad$ p ... ploskev

lok ... lokalno, reg ... regionalno, giob ... globalno 
Tabela 2: Uporaba podatkov $v$ odvisnosti od merila in izvora podatkov. modul merila

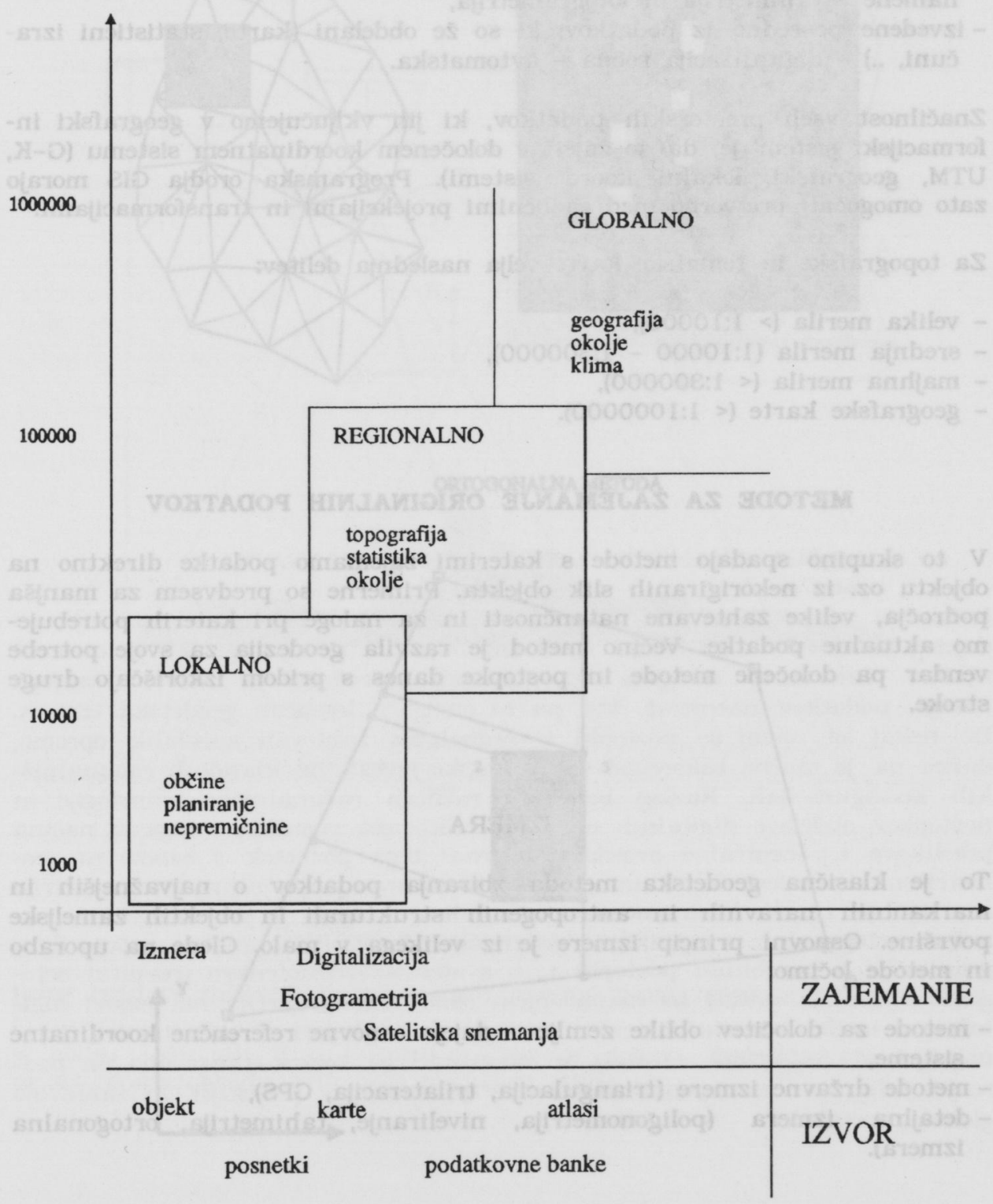


Glede na izvor podatkov ločimo:

- osnovne, originalne neposredno $z$ meritvami na objektu pridobljene podatke oz. nekorigirane slike objekta - primerne za topografsko kartografske namene - tahimetrija in fotogrametrija,

- izvedene posredno iz podatkov, ki so že obdelani (karte, statistični izračuni, ..) - digitalizacija ročna - avtomatska.

Značilnost vseh prostorskih podatkov, ki jih vključujemo $v$ geografski informacijski sistem je, da so zajeti $v$ določenem koordinatnem sistemu (G-K, UTM, geografski, lokalni koord. sistemi). Programska orodja GIS morajo zato omogočati pretvorbo med različnimi projekcijami in transformacijami.

Za topografske in tematske karte velja naslednja delitev:

- velika merila (> 1:10000),

- srednja merila (1:10000 - 1:300000),

- majhna merila $(<1: 300000)$,

- geografske karte (< 1:1000000).

\section{METODE ZA ZAJEMANJE ORIGINALNIH PODATKOV}

$\mathrm{V}$ to skupino spadajo metode $\mathrm{s}$ katerimi zajemamo podatke direktno na objektu oz. iz nekorigiranih slik objekta. Primerne so predvsem za manjša področja, velike zahtevane natančnosti in za naloge pri katerih potrebujemo aktualne podatke. Večino metod je razvila geodezija za svoje potrebe vendar pa določene metode in postopke danes $s$ pridom izkoriščajo druge stroke.

\section{IZMERA}

To je klasična geodetska metoda zbiranja podatkov o najvažnejših in markantnih naravnih in antropogenih strukturah in objektih zameljske površine. Osnovni princip izmere je iz velikega $v$ malo. Glede na uporabo in metode ločimo:

- metode za določitev oblike zemlje - dajejo osnovne referenčne koordinatne sisteme,

- metode državne izmere (triangulacija, trilateracija, GPS),

- detajlna izmera (poligonometrija, niveliranje, tahimetrija, ortogonalna izmera). 
DRŽAAVNA IZMERA

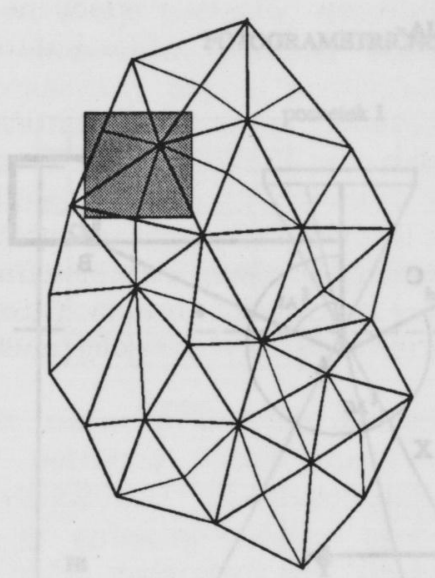

LORALNA IZMERA

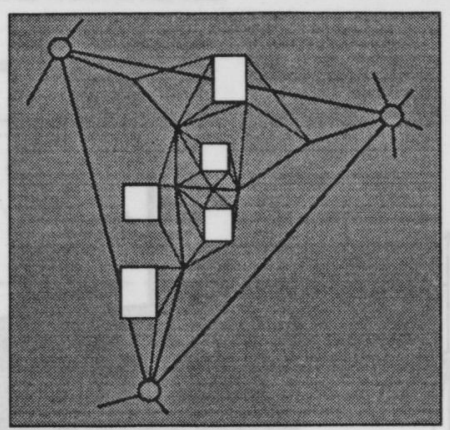

ORTOGONALNA METODA

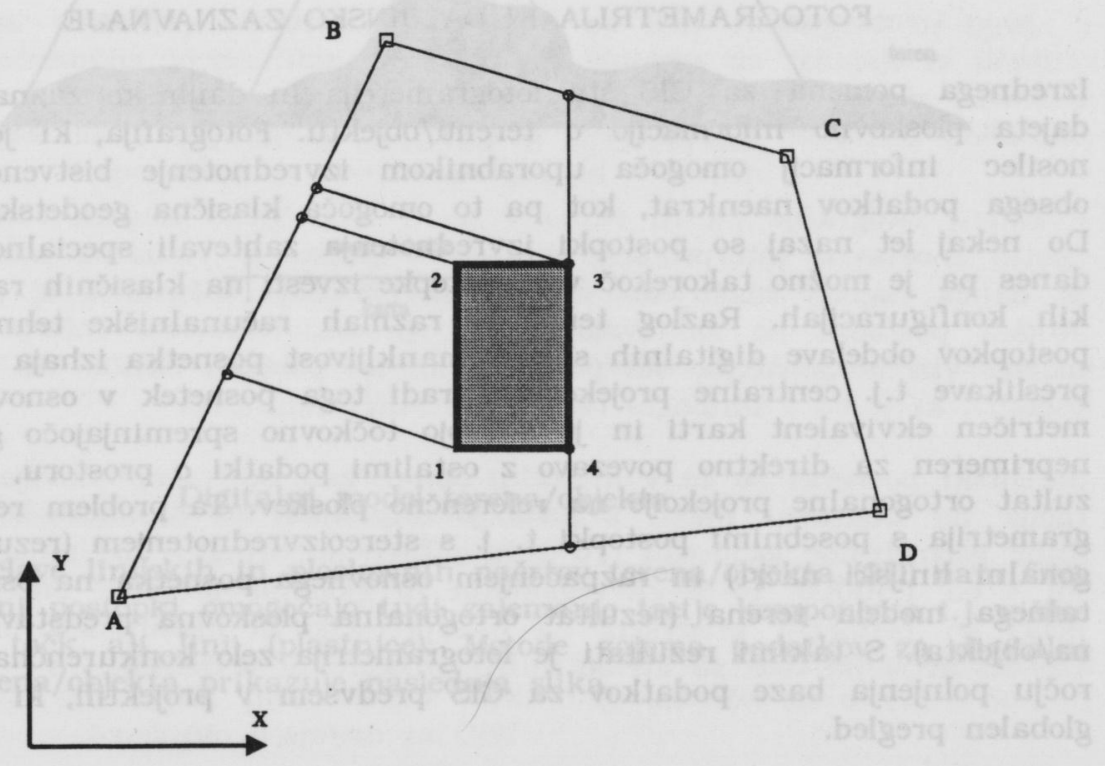


Shema 1: Metode izmere.

TAHIMETRUA
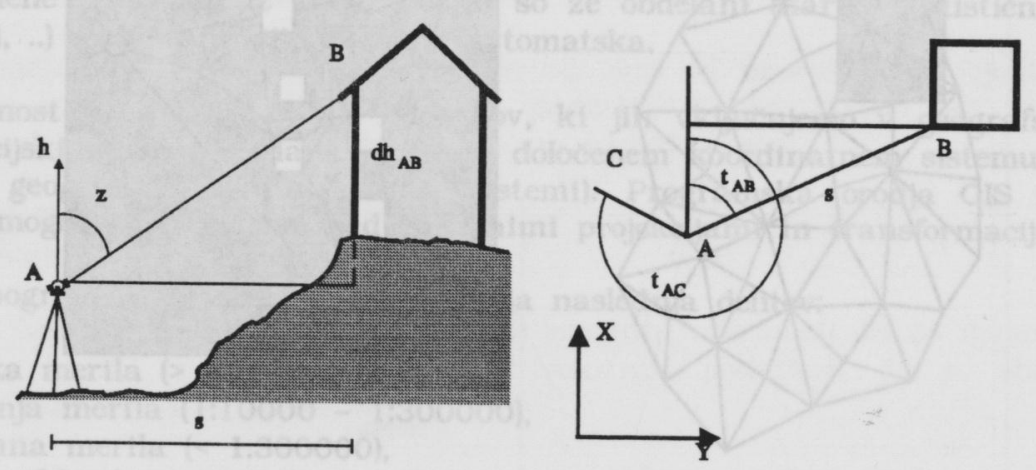

FOTOGRAMETRIJA IN DALJINSKO ZAZNAVNAJE

Izrednega pomena za GIS sta fotogrametrija in daljinsko zaznavanje, ki dajeta ploskovno informacijo o terenu/objektu. Fotografija, ki je osnovni nosilec informacij omogoča uporabnikom izvrednotenje bistveno večjega obsega podatkov naenkrat, kot pa to omogoča klasična geodetska izmera. Do nekaj let nazaj so postopki izvrednotenja zahtevali specialno opremo, danes pa je možno takorekoč vse postopke izvesti na klasičnih računalniških konfiguracijah. Razlog temu je razmah računalniške tehnologije in postopkov obdelave digitalnih slik. Pomankljivost posnetka izhaja iz načina preslikave t.j. centralne projekcije. Zaradi tega posnetek $v$ osnovi ni geometričen ekvivalent karti in je $s$ svojo točkovno spreminjajočo geometrijo neprimeren za direktno povezavo $\mathrm{z}$ ostalimi podatki o prostoru, ki so rezultat ortogonalne projekcíije na referenčno ploskev. Ta problem rešuje fotogrametrija $s$ posebnimi postopki t. j. s stereoizvrednotenjem (rezultat ortogonalni linijski načrt) in razpačenjem osnovnega posnetka na osnovi digitalnega modela terena (rezultat ortogonalna ploskovna predstavitev terena/objekta). S takimi rezultati je fotogrametrija zelo konkurenčna na področju polnjenja baze podatkov za GIS predvsem v projektih, ki zahtevajo globalen pregled. 
Shema 2: Fotogrametrično zajemanje podtkov.

\section{FOTOGRAMETRIČNO STEREOIZVREDNOTENEJE}
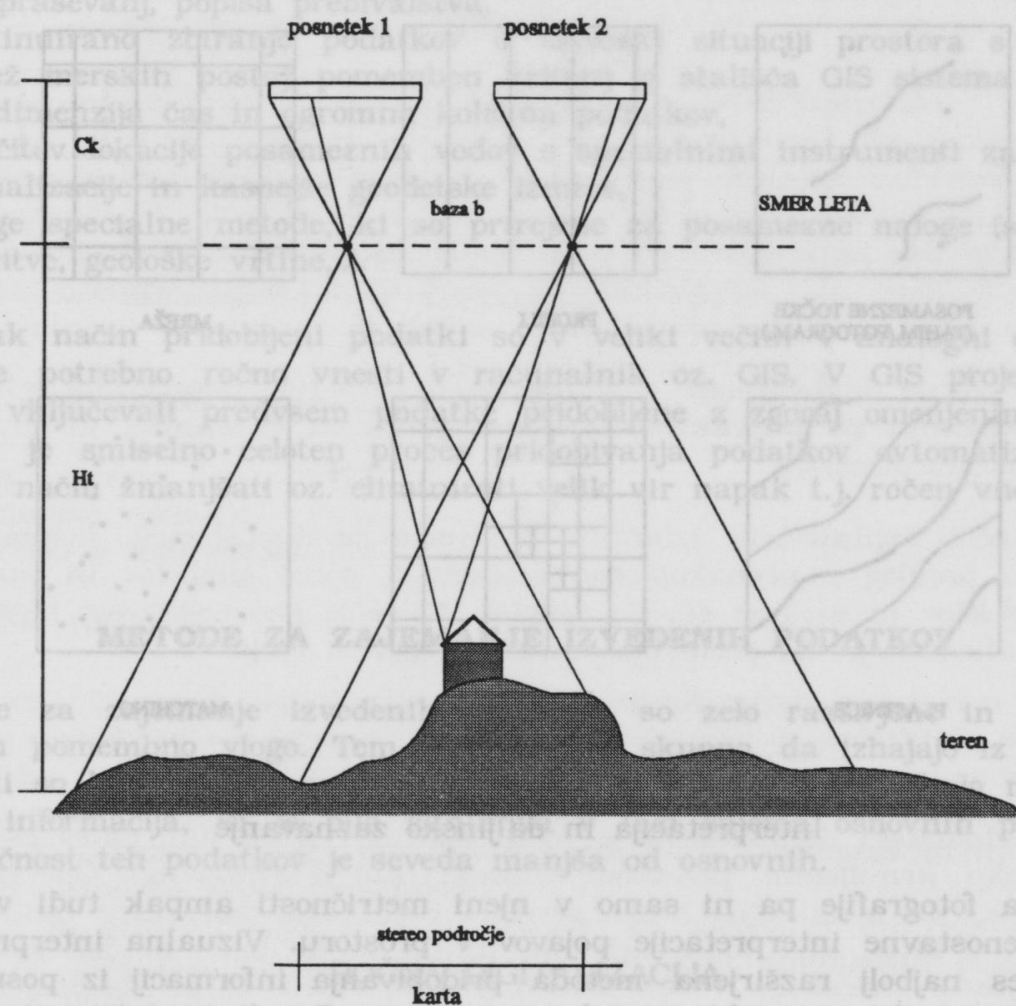

Digitalni model terena/objekta

Poleg izdelave linijskih in ploskovnih načrtov terena/objekta (2D) nam fotogrametrični postopki omogočajo tudi zajemanje tretje komponente t.j. višine v obliki točk ali linij (plastnice). Metode zajema podatkov za digitalni model terena/objekta prikazuje naslednja slika. 
Shema 3: Metode zajemanja DMR.

\section{METODE ZA ZAJEMANJE DMR}

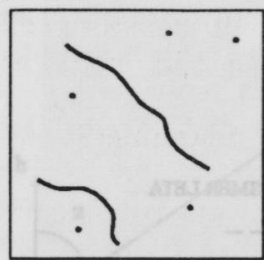

POSAMEZNR TOCKKB (TAHIM/ROTOCGRAM.)

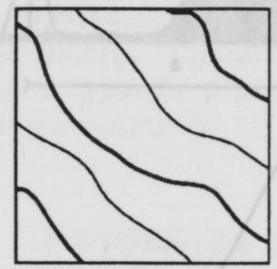

PLASTNICB

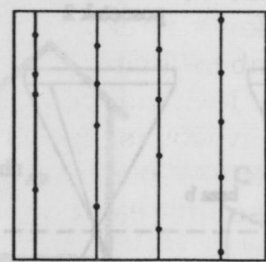

PROFII

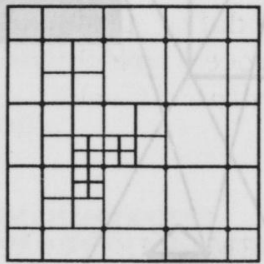

PROGRESSIVE SAMPLING

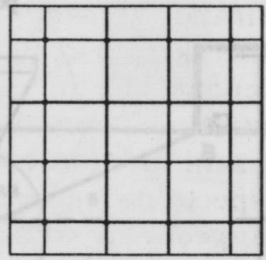

MREž̀A

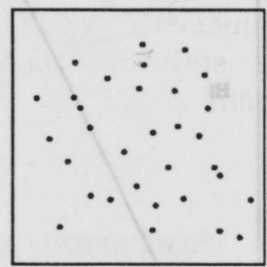

MATCHING

Interpretacija in daljinsko zaznavanje

Kvaliteta fotografije pa ni samo $v$ njeni metričnosti ampak tudi $v$ možnostih enostavne interpretacije pojavov $\mathrm{v}$ prostoru. Vizualna interpretacija je danes najbolj razširjena metoda pridobivanja informacij iz posnetkov. Takšni postopki ne zahtevajo drage opreme. Rezultate interpretacije je možno vnašati direktno na posnetek ali na posebno oleato. To "izluščeno" vsebino, ki je še $\mathrm{v}$ analogni obliki, nato digitaliziramo.

Satelitski posnetki so že $\mathrm{V}$ digitalni obliki, zato se na njih izvaja interpretacija na digitalen način $s$ pomočjo algoritmov in računalnikov. Zaradi slabe geometrične ločljivosti $(10-20 \mathrm{~m}$ piksel) so primerni za naloge v merilih < od 1:50000, to je za regionalne in globalne projekte. Satelitski posnetki so primerni predvsem za interpretacijo in klasifikacijo iz stališča GIS-sistemov pa tudi za atributiranje prostorskih podatkov.

\section{DRUGE METODE}

Številne stroke uporabljajo za pridobivanje predsvem tematskih informacij, ki se nanašajo na prostor (geološke strukture, vrsta rabe, pravno-administrativne strukture, statistični, sociološki in naravni fenomeni, arheološka najdišča,..) še širok spekter metod zajema podatkov kot npr.: 
- terenska merjenja, ki dajejo diskretne in zvezne podatke (meritve temperature, štetje prometa, onesnaženje ozračja,...),

- socio-ekonomski podatki dobljeni $\mathrm{v}$ obliki intervjujev, reprezentativnih povpraševanj, popisa prebivalstva,

- kontinuirano zbiranje podatkov o ekološki situaciji prostora $\mathrm{s}$ pomočjo mrež merskih postaj; pomemben kriterij iz stališča GIS sistema je četrta dimenzija čas in ogromna količina podatkov,

- določitev lokacije posameznih vodov s specialnimi instrumenti za potrebe signalizacije in kasnejše geodetske izmere,

- druge specialne metode, ki so prirejene za posamezne naloge (seizmične meritve, geološke vrtine,...).

$\mathrm{Na}$ tak način pridobljeni podatki so $\mathrm{v}$ veliki večini $\mathrm{v}$ analogni obliki in jih je potrebno ročno vnesti $v$ računalnik oz. GIS. V GIS projektih, ki bodo vključevali predvsem podatke pridobljene $z$ zgoraj omenjenimi metodami, je smiselno celoten proces pridobivanja podatkov avtomatizirati in na ta način zmanjšati oz. eliminirati velik vir napak t.j. ročen vnos podatkov.

\section{METODE ZA ZAJEMANJE IZVEDENIH PODATKOV}

Metode za zajemanje izvedenih podatkov so zelo razširjene in igrajo $\mathrm{v}$ GIS-ih pomembno vlogo. Tem metodam je skupno, da izhajajo iz produktov, ki so bili izdelani za določen namen in $\mathrm{v}$ katerih se nahaja natančno tista informacija, ki je bila zanimiva $v$ fazi zajema osnovnih podatkov. Natančnost teh podatkov je seveda manjša od osnovnih.

\section{ROČNA DIGITALIZACIJA}

Digitalizacija (ročna ali avtomatska) obstoječega kartnega materiala je najčešča metoda zajemanja podatkov za GIS. Razlog za uporabo teh metod je:

- obstoj zelo velikega števila analognih kart,

- v številnih projektih so se metode obnesle,

- enostavnost $v$ fazi dela.

Pri ročni digitalizaciji igra človeški faktor veliko oz. najpomembnejšo vlogo; razpoznava pomebnost posameznih točk, linij, površin in direktno kodira geometrijo ter topologijo potrebno za GIS.

Oblike ročne digitalizacije so:

- "špageti" digitalizacija,

- digitalizacija po linijah,

- digitalizacija $z$ upoštevanjem topologije. 
Shema 4: Oblike ročne digitalizacije.
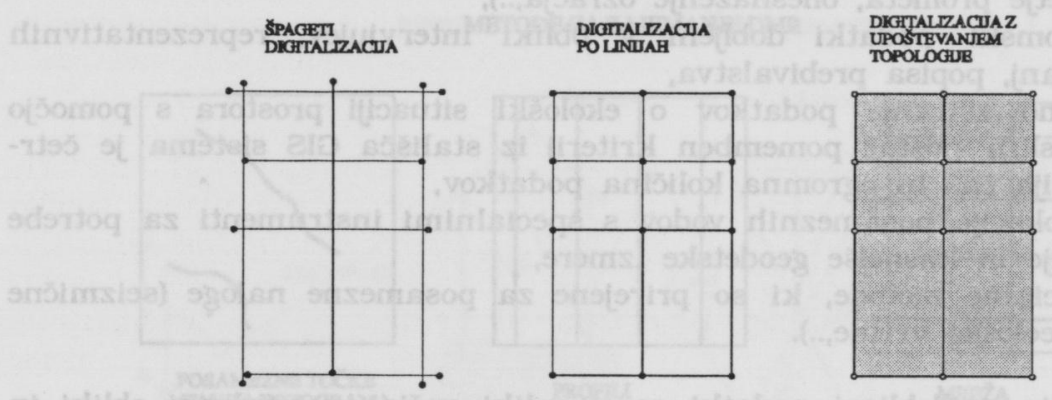

Prednost ročne digitalizacije je $\mathrm{v}$ udobnosti in $\mathrm{s}$ tem povezanimi minimalnimi potrebami po interaktivnem popravljanju in $v$ tehniki, ki jo lahko uporabimo vsepovsod.

Ročni način digitalizacije izbiramo predvsem za digitalizacijo kompleksnih grafičnih predlog $\mathrm{z}$ neenakomerno geometrijo, polno simbolov in različnih oblik objektov in majhno število načrtov. Največja pomanjkljivost tega načina digitalizacije je, da potrebujemo veliko časa in ljudi.

\section{POLAVTOMATSKA DIGITALIZACIJA}

Pri polavtomatski digitalizaciji je ročno vodenje vzdolž linij nadomeščeno $z$ avtomatsko krmiljenim procesom sledenja linij (linefolowing). Operaterjeva naloga je, da identificira linijo, nastavi zahtevane parametre (min./max. odprtina v liniji, min./max. debelina linij,..) in atribute, ki določajo vrsto linije/objekta. Investicija $v$ tak sistem je zelo velika in se obrestuje le pri velikem obsegu dela in specifičnih kartografskih podlagah (oleate plastnic, oleate hidrografije,..) kjer s takimi sistemi naredimo $10 x$ več kot $z$ ročno digitalizacijo in $2 \mathrm{x}$ več kot $\mathrm{z}$ avtomatsko digitalizacijo. Postopek je popolnoma neekonomičen za digitalizacijo predlog $v$ velikih merilih, kjer je še vedno najuspešnejša ročna digitalizacija.

\section{AVTOMATSKA DIGITALIZACIJA/SKANIRANJE}

V procesu avtomatske digitalizacije je vloga operaterja omejena le še na vstavljanje grafične predloge $\mathrm{v}$ skaner. Rezultat postopka avtomatske digitalizacije je matrika sivih vrednosti. Tako dobljena slika lahko služi kot podlaga (ozadje) za orientacijo oz. je osnova za postopek raster/vektor pretvorbe (vektorizacije) $\mathrm{v}$ katerem objektno strukturiramo elemente slike oz. jih topološko povežemo. Avtomatski postopki raster/vektor pretvorbe so danes operativni le za specifične grafične predloge (plastnice, hidrografija,..) $z$ enakomerno geometrijo in zahtevajo dobro predpripravo (ročno) in veliko geometrično resolucijo rastrske slike (500 in več dpi). 


\section{KVALITETA PODATKOV}

Pred in med zajemom podatkov o prostoru je potrebno kritično oceniti kvaliteto podatkov in njihovo primernost za različne naloge. $\mathrm{V}$ nadaljevanju bodo prediskutirani možni viri pogreškov.

Za neposredno zajete podatke (tahimetrično, fotogrametrično) lahko zelo natančno določimo njihovo natančnost in zanesljivost. $Z$ a veliko število podatkov (opisni podatki, izvedeno podatki) ne obstajajo informacije o njihovi natančnosti, prav tako pa je $v$ velikem številu primerov celo nepoznana osnovna metoda zajemanja. Kljub temu pa moramo na nek način za te podatke oceniti njihovo natančnost in zanesljivost, da zadovoljimo pogoj konsistentnosti prostorskih podatkov uporabljenih $\mathrm{v}$ GIS.

Možne vire pogreškov razdelimo v:

- splošne vzroke,

- prostorske variacije,

- pogreški v fazi obdelave.

Splošni vzroki

- Različna "starost" podatkov: različni standardi zajemanja; s tem so povezane metode in natančnost. Preveriti je treba, če so podatki še veljavni.

- Različna gostota pokrivanja prostora: v praksi je pokrivanje prostora zelo nehomogeno - teoretično bi radi imeli enakomerno pokrivanje. S tem je povezana optimalna določitev intervala zajemanja in interpolacijskih metod za zapolnitev "lukenj".

- Merilo in generalizacija: izvedeni podatki so dobljeni v procesih pri katerih ne obstajajo več informacije o razporeditvi originalnih podatkov in njihovi natančnosti.

- Zapis podatkov v digitalno obliko: vrsta formatov za kodiranje in za same podatke (merilo, projekcija), vplivajo na zmanjšanje natančnosti.

- Razpoložljivost in stroški: velikokrat vplivajo politični razlogi, stroški, zaščita podatkov, da ne moremo dobiti na razpolago izvornih podatkov. Ponovno zajemanje izvornih podatkov ponavadi zaradi stroškov ne pride $\mathrm{v}$ poštev.

Prostorske variacije

Vsi prostorski podatki že po naravi varirajo za določene vrednosti:

- Pozicijska natančnost: različne natančnosti podatkov so odvisne od metode zajemanja, velikosti področja in vrste podatkov.

- Vsebinska natančnost: postavlja se vprašanje pravilnosti in reprezentativnosti posameznih atributov, ki so dodani objektom.

- Naravne variacije podatkov: pogreški merjenja in interpretacije, ločljivost, primerljivost, možnost reprodukcije merskih rezultatov. 
Pogreški v fazi obdelave

- natančnost računskih operacij izvedenih $z$ računalnikom: pogreški zaokroževanja, max. številska vrednost spremenljivk - povezava $z$ velikostjo obdelovanega področja, izbor neprimernih formatov za predstavitev prostorskih podatkov.

- napačne predpostavke: veliko algoritmov za obdelavo prostorskih podatkov izhaja iz predpostavk, ki pa jih večina podatkov ne izpolnjuje. Najčešče predpostavke:

- enakomerna porazdelitev podatkov,

- digitalizacija brez pogreškov,

- ravninska geometrija ne upošteva spačenja pri preslikavi delov zemelj. površ. na ravnino,

- dobro definirane meje med objekti,

- splošne klasifikacije objektov in njim pripadajočih atributov

- pogreški pri zajemanju in obdelavi: napačne klasifikacije, pogreški generalizacije, inter- oz. ekstrapolacije, uporaba neprimernih metod za določene tipe podatkov - povzročajo nepredvidljive velikosti pogreškov.

Največji vpliv na natančnost digitaliziranih podatkov imata pogrešek kartiranja in pogrešek digitalizacije. Na splošno velja, da je natančnost ročnega kartiranja $1 / 10$ - $1 / 20 \mathrm{~mm}$. Največji vir pogreškov je osebni pogrešek operaterja. V primeru strojnega kartiranja je natančost podana $z$ natančnostjo instrumenta, ki lahko doseže do $1 / 100 \mathrm{~mm}$ (vektor ploterji). Digitalizacija je vedno manj natančna od kartiranja, zato so končni rezultati odvisni od natančnosti digitalizacije.

\section{KONTROLA PODATKOV}

Pri zajemanju podatkov predstavlja največji problem kontrola zajetih podatkov. Ta proces vsebuje preverjanje popolnosti, zanesljivosti, pravilnosti in jasnosti podatkov in $s$ tem vsebine GIS-a.

Imamo lahko opravka s pre- (večkratna določitev $\mathrm{z}$ minimalnimi odmiki) ali poddefiniranimi (manjkajoče informacije) informacijami, ki jih zajeti podatki dajejo. V prvem primeru gre za čiščenje podatkov, ki ima za posledico podatke brez redundance. V drugem primeru moramo podatke doploniti. Kontrolirati moramo tudi geometrično kvaliteto glede na uporabo podatkov za različne namene. Kontrola podatkov ima v GIS-u pomembno vlogo, kajti slabi podatki so brez vrednosti in lahko rezultati dobljeni iz takih podatkov, zavajajo. Do sedaj nekritični odnos uporabnikov GIS do kvalitete podatkov bo $\mathrm{v}$ bližnji prihodnosti povzročil enormna popravljanja ob velikh stroških. Obstajajo različne metode kontrole. Odvisne so od vrste zajetih podatkov (vektor, raster, opisni), razpoložljivih instrumentov in poznavanja objekta. 
Najenostavnejša metoda kontrole, je vizualna primerjava originala in digitaliziranih podatkov. Napake označimo in jih naknadno popravimo. Pri alfanumeričnih podatkih lahko $z$ manjšimi programi izločimo grobe napake (koordinate so izven dovoljenega obsega, predznak,...). Na podoben način lahko kontroliramo tudi atribute, ki pripadajo objektom (ali atribut obstaja,...). Za digitalni model se splača narediti perspektivne izrise ali plastnice $s$ čimer prav tako vizualno izločimo grobe napake. Pri delu $z$ analitičnimi ploterji nam $v$ veliki meri pomaga superimpozicija (mono - popolnost podatkov, stereo - 3D geometrija).

\section{VZDRŽEVANJE PODATKOV}

Podatki v GIS-u izgubljajo s časom hitro svojo vrednost, če jih permanentno ne vzdržujemo. Aktualizacija podatkov je neprekinjen proces s katerim prevedemo digitalno vsebino na tekoče stanje. Podatki v GIS-u predstavljajo vedno samo določen trenutek in to vedno realno stanje.

Izjeme so aplikacije za področje okolja in zgodovinske dediščine. Frekvenca vzdrževanja je odvisna od vrste podatkov, ki so v GIS-ih:

- manjša frekvenca - geografski in administrativni podatki,

- večja frekvenca - izraba zemljišča, lastništvo, ...

Vzdrževanje podatkov je časovno intenziven interaktivni proces, ki lahko včasih traja dlje kot pa osnoven zajem podatkov. To je seveda povezano $z$ velikimi stroški, zato je potrebno dobro razmisliti ali bomo vzdrževanje izvajali postopoma kot nastajajo ali bomo $\mathrm{v}$ določenih časovnih intervalih aktualizirali celotno bazo naenkrat. V grobem lahko rečemo:

- vektorske podatke vzdržujemo "per partes",

- rastrske podatke $\mathrm{v}$ celoti $\mathrm{v}$ enem koraku zamenjamo $\mathrm{z}$ novimi.

\section{PRAKTIC̆NE IZKUŠNJE}

S problematiko zajema podatkov se $\mathrm{z}$ ozkim krogom sodelavcev ukvarjamo že tri leta. V tem času smo izoblikovali svoj koncept in pogled na problematiko zajema podatkov iz grafičnih predlog. Seveda niso naša razmišljanja in rešitve $\mathrm{v}$ konfliktu $\mathrm{s}$ postopki in metodami opisanimi $\mathrm{v}$ uvodnih poglavjih. Poizkušali smo samo združiti rešitve, ki so se nam zdele optimalne za naše potrebe in konkretne naloge. Našo dejavnost smo usmerili na več področij:

- konzultantstvo,

- izdelava aplikativnih programskih rešitev,

- operativa. 
Svoje delo in izkušnje združujemo s skupino za GIS-e in skupaj ponujamo sistemske rešitve. S takšnim spektrom dejavnosti smo danes sposobni pokriti velik del želja in potreb naročnikov.

\section{KONZULTANTSTVO}

Zelo važno je v fazi uvajanja (implementacije) GIS ugotoviti, čemu bo GIS koristil oz. komu bo namenjen. Marsikdo bo rekel to je jasno, vendar so izkušnje iz preteklosti in naši prvi kontakti $z$ naročniki pokazali, da njihove poslovne analize največkrat niso izdelane eksaktno. Rezultat tega je, da se konvertira veliko več podatkov kot pa je nujno potrebno. Veliko je $\mathrm{k}$ takemu razmišljanju in delovanju prispeval nesmiseln argument, da je vektorskih podatkov tako malo, da ni važno, če jih zajamemo nekoliko več kot je potrebno, zato pa imamo prednost, da razpolagamo $z$ digitalnimi podatki večjega področja (nihče ni mislil na vzdrževanje). Največkrat te analize tudi ne dajejo stabilnega časovnega okvirja $v$ katerem se mora projekt uspešno zaključiti v vseh svojih fazah.

Naš pristop izhaja iz predpostavke, da $\mathrm{v}$ center projekta postavimo GIS in upoštevamo njegove organizacijske zahteve in iz tega izpeljemo oz. definiramo celotno poslovno politiko projekta.

Rezultat takega pristopa je:

- določitev končnih uporabnikov sistema (vključujoč tudi tiste, ki mogoče ne bodo nikoli sedli za računalnik),

- detajlni pregled aktivnosti na sistemu,

- ocena potrebnosti informacij (ist-analyse, kaj želimo),

- kateri podatki (karte, načrti, kartoteke, liste, zapiski,...) obstajajo?

- kje se nahajajo podatki?

- kakšna je aktualnost podatkov?

- v kakšni obliki obstajajo podatki?

- katere pomožne podatke bomo potrebovali?

- kje se pomožni podatki nahajajo?

- katere podatke bomo uporabljali za prezentacijo?

- v kakšni obliki (frekvenca, obseg,..) rabimo te podatke?

- kdo potrebuje in kdo uporablja te podatke?

- kako se bodo ti podatki uporabljali?

- nabava vseh virov podatkov in metod zajema,

- preverjanje kvalitete (pokrivanje področja, starost, natančnost,...) izhodnih podatkov oz. metod zajema,

- preverjanje pomembnosti, primernosti in uporabnosti virov podatkov in metod zajema podatkov,

- modeliranje podatkov,

- konkretno zajemanje podatkov kot kombinacija zajema osnovnih in izvedenih podatkov,

- vizijo oz. pregled možnih zahtev do postavljenega sistema v bodočnosti. 
Iz analize lahko natančno določimo potrebe po podatkih, vključujoč zahtevan obseg in zahtevano inteligenco $\mathrm{v}$ strukturi podatkov ter časovni okvir izvedbe projekta. Svetovne in tudi naše izkušnje kažejo, da morajo biti projekti oz. njihova izvedba planirani tako, da imamo najkasneje $v$ letu do 18 mesecih na razpolago sistem in podatke, za katere smo se dogovorili. Če ta časovni okvir prekoračimo bo postalo vodstvo (management) nestrpno, ker ne bo videlo rezultatov. Vzroki za probleme bodo najverjetneje $\mathrm{v}$ osnovnem zajemanju podatkov in celotne tehnologija ter postopki bodo prišli na slab glas. Lahko bi rekli:

če neka organizacija $v$ danem trenutku ni zmožna pridobiti zadosti finančnih sredstev in ustreznih izvornih materialov, da bi lahko projekt zaključila v prej omenjenem času, je bolje, da počaka na ugodnejši trenutek.

\section{APLIKATIVNE PROGRAMSKE REŠITVE}

$\mathrm{Na}$ področju zajema podatkov za GIS-e poizkušajo proizvajalci GIS programskih orodij uveljaviti koncept univerzalnosti t.j. $z$ enim programskim paketom (sestavljen iz več modulov) pokriti celotno področje od zajema, preko analiz do prezentacije podatkov. Tak pristop ima po našem mnenju poleg vseh prednosti vsaj dve bistveni pomanjkljivosti:

- univerzalnost ni združljiva s specialnimi problemi,

- univerazalnost zahteva sposobne strojne komponente reda delovne postaje $z$ ogromnim RAM-om in trdim diskom.

Naš koncept je seveda delno pogojen $z$ zatečenim stanjem na področju opremljenosti s strojno opremo (prevladujejo PC). Bistveno pa je bilo naše prepričanje, da smo sposobni $z$ lastno izdelano namensko programsko opremo in na primerno opremljenem PC-ju (4-8 MB RAM-a, trdi disk

Shema 5: Naš koncept zajema podatkov za GIS.

ZAJEM

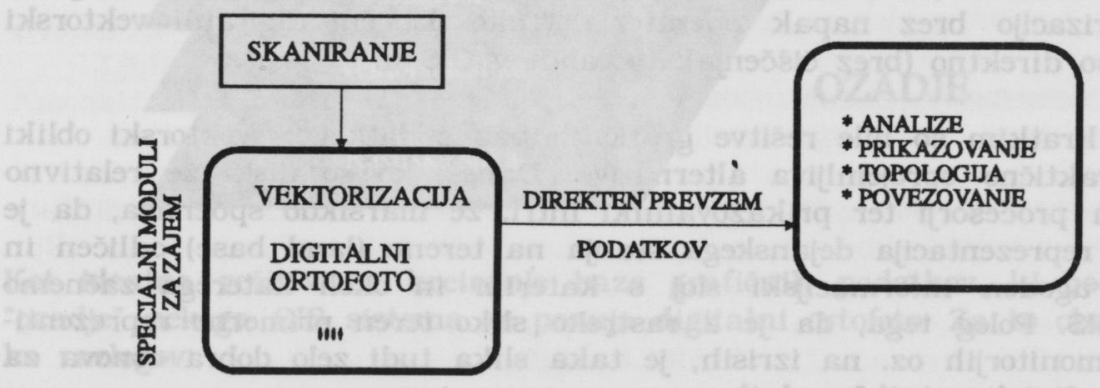

GIS DELOVNA ENOTA
OSEBNI RAČUNALNIK 
100-200 MB) uspešno izvajati naloge, ki so povezane z zajemom podatkov. Najvažnejša od vseh odločitev pa je bila, da smo se že na samem začetku, ko je skoraj vsa domača strokovna javnost dvomila $v$ avtomatsko digitalizacijo t.j. skaniranje, odločili za skaniranje grafičnih predlog z naknadno head up vektorizacijo ( $v$ specialnih primerih za polavtomatsko vektorizacijo). Po krajšem kolebanju smo iz naših razmišljanj izbrisali avtomatsko vektorizacijo, ker je trenutno:

- učinkovita samo v laboratorijskih razmerah,

- operativna samo za specialne naloge.

Ker smo po stroki geodeti, je bila naša prva želja in hkrati prva praktična naloga pri kateri smo se srečali $z$ zahtevo po digitalizaciji grafičnih predlog, nastavitev digitalne baze zemljiškega katastra in s tem povezana naloga digitalizacije katastrskih načrtov. Za potrebe te naloge smo izdelali programsko orodje, ki omogoča:

- prikazovanje binarnih in sivih rastrskih slik,

- head up ročno vektorizacijo na zaslonu,

- avtomatsko snap funkcijo,

- ročni vnos parcelnih številk,

- natančnost vektorizacije velikostnega reda piksla,

- delo s fiksnimi okni, kar bistveno pripomore $\mathrm{k}$ zmanjšanju napak vektorizacije,

- vizualno kontrolo pravilnosti vektorizacije,

- 4 ravninske transformacije (iz pikslov $v$ koordinatni sistem lista),

- topološke kontrole,

- minimalen izhodni vektorski format (za arhiviranje),

- direkten zapis vektorskih podatkov $\mathrm{v}$ ARC/INFO in DXF format.

Program je zelo enostaven in se ga lahko vsak operater priuči najkasneje v pol ure. Njegovo učinkovitost pa potrjuje dejstvo, da do sedaj še nismo naleteli na program za vektorizacijo katastrskih načrtov, ki bi $\mathrm{v}$ enakem času dajal enako kvalitetne rezultate. Velika prednost tega programa so topološke kontrole (so bistveno hitrejše kot tiste v GIS orodjih), ki omogočajo vektorizacijo brez napak operaterja. Tako dobljeni digitalni vektorski podatki so direktno (brez čiščenja) uporabni v GIS-u.

Do pred kratkim so bile rešitve grafičnih baz podatkov v vektorski obliki edina praktično sprejemljiva alternativa. Danes, ko so diski že relativno poceni in procesorji ter prikazovalniki hitri, že marsikdo spoznava, da je rastrska reprezentacija dejanskega stanja na terenu (land base) odličen in cenovno ugoden informacijski sloj $s$ katerim in okoli katerega začnemo graditi GIS. Poleg tega, da je $z$ rastrsko sliko teren primerno reprezentiran na monitorjih oz. na izrisih, je taka slika tudi zelo dobra osnova za zajemanje "inteligentnih" podatkov. 
Za infrastrukturne dejavnosti je primerno, da so podatki razdeljeni $v$ dva nivoja:

- ozadje (background) in

- uporabniške informacijske sloje (foreground)

s katerimi posamezne dejavnosti upravljajo (shema 6).

Trenutno je vir za podatke $v$ ozadju kvaliteten načrt na papirju, ki ga ponuja geodetska služba (TTN5,TTN10). V danem trenutku pa ponavadi ne razpolagamo $s$ kompletnim digitalnim prikazom področja, ki nas zanima, oz. je nastavitev takšne grafične baze predraga za obseg konkretnega projekta. Ena od rešitev je, da obstoječe načrte skaniramo. Cena za pridobitev podatkov ozadja $v$ rastrski obliki je cenovno bistveno ugodnejša, kot pa popolna konverzija v vektorsko obliko (mogoče samo 10\% stroškov vektorizacije). Kljub temu rešitev $z$ rastrsko sliko načrta na dolgi rok ne prinaša bistvenih prednosti, saj še vedno ostaja problem učinkovitega in cenovno sprejemljivega sistema za vzdrževanje.

Shema 6: Osnouni podatkouni model grupiranja informacij.

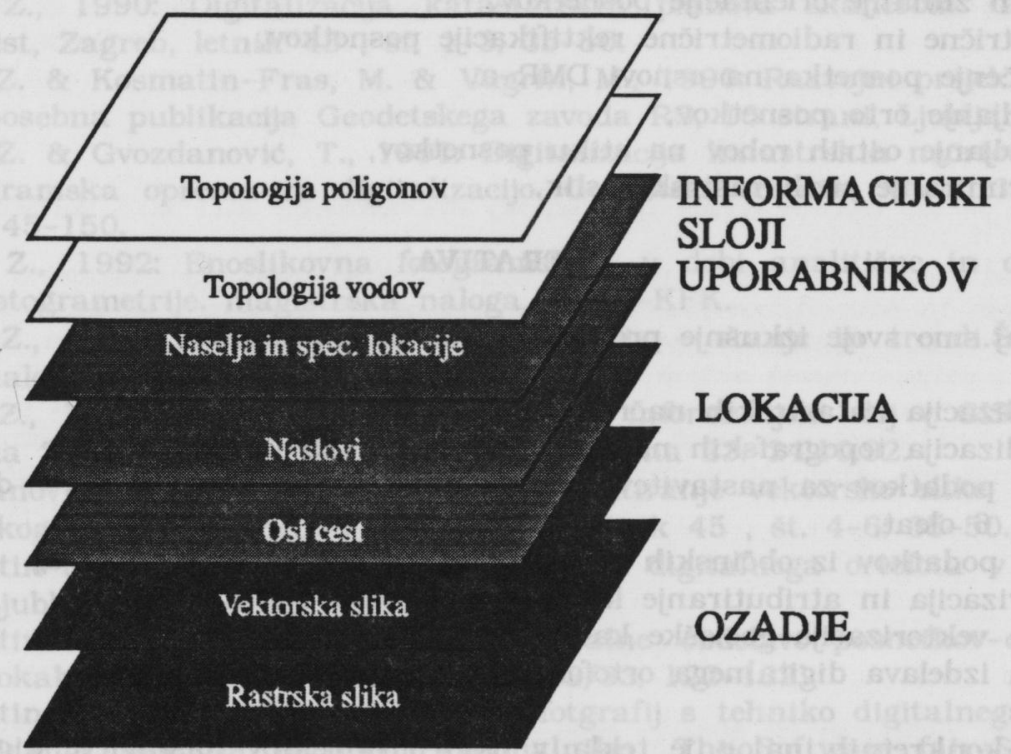

Kot idealna rešitev za kreiranje baze grafičnih podatkov, ki bodo tvorili "ozadje" nekega GIS sistema se ponuja digitalni ortofoto. Za to obstaja veliko razlogov:

- z vsebino, ki jo združuje predstavlja splošno prostorsko bazo,

- zagotovljena je ortogonalna projekcija (kot na karti) in absolutna orienta- 
cija v ravnini prikazovanja (npr. direktno v G.K. sistemu), zato se natančno prilagaja vektorski sliki,

- zelo enostavno je narediti izvlečke različnih natančnosti, ki so prilagojeni različnim uporabnikom, kljub temu pa je ohranjena enotna informacijska osnova,

- zmožnosti računalnikov na področju upravljanja $z$ rastrskimi podatki so danes že takšne, da to $v$ resnih projektih več ne predstavlja problema,

- tam kjer je utečeno ciklično snemanje terena, je vzdrževanje te osnovne baze zelo enostavno,

- omogoča nam digitalizacijo določenih zanimivih objektov s postopkom vektorizacije po zaslonu,

- sodobna GIS programska oprema omogoča enostavno združevanje rastrskih in vektorskih podatkov.

Zaradi vseh naštetih razlogov smo se odločili, da je primeren čas ponuditi uporabnikom program za izdelavo digitalnega ortofota oz. jim ponuditi izdelek na disketi. Testna verzija programa, ki smo jo razvili v zadjega pol leta teče na PC-ju in omogoča:

- določitev oslonilnih točk na sivi rastrski sliki,

- izračun zunanje orientacije posnetkov,

- geometrične in radiometrične rektifikacije posnetkov,

- razpačenje posnetka na osnovi DMR-a,

- sestavljanje orto posnetkov,

- odpravljanje ostrih robov na stiku posnetkov,

- komprimiranje sivih rastrskih slik.

\section{OPERATIVA}

Do sedaj smo svoje izkušnje preizkusili na večih nalogah:

- digitalizacija katastrskih načrtov (250 listov),

- digitalizacija topografskih načrtov v M 1:500 (15 listov),

- zajem podatkov za nastavitev baze digitalnih podatkov terena - digitalizacija 6 oleat,

- zajem podatkov iz občinskih planskih aktov (24 listov M 1:5000),

- vektorizacija in atributiranje kompletne vsebine 4 listov TTN 5 ,

- testna vektorizacija geološke karte,

- testna izdelava digitalnega ortofota 1 lista v M 1:5000.

Večina konkretnih nalog je tekla $\mathrm{v}$ okviru projektov nastavitve digitalnih baz prostorskih podatkov, ki so organizirani okoli GIS programskih orodij.

\section{ZAKLJUČEK}

$\mathrm{I} z$ vsega kar je povedano $\mathrm{v}$ predhodnih poglavjih izhaja, da predstavlja zajem podatkov za GIS kar velik zalogaj, če ga želimo v popolnosti obvladovati. Redki so centri $v$ svetu, ki so usposobljeni za zajemanje original- 
nih in izvedenih podatkov. Sami smo se odločili, da pristopimo $\mathrm{k}$ problemu v manjših korakih, ki jih želimo čim bolje obvladovati. Zaenkrat smo se osredotočili na zajem izvedenih podatkov in še to operativno samo za potrebe zemljiškega katastra in TTN 5. Sočasno testiramo programska orodja za potrebe drugačnih projektov (geologija, arhitektura, manjša merila,..). Ne zanemarjamo pa tudi metod zajema originalnih podatkov. V vseh svojih aktivnostih imamo vedno pred očmi dvoje:

- od kvalitete podatkov je odvisna kvaliteta GIS-a, zato je potrebno posvetiti veliko pozornosti postopkom za zajem podatkov,

- zajem podatkov, ki ni del neke sistemske rešitve, je metanje denarja $v$ jamo brez dna.

\section{VIRI IN LITERATURA}

Bill, R. \& Fritch, D., 1991: Grundlagen der Geo-Informations systeme, Band I, Herbert Wichman Verlag, Karlsruhe.

Baehr, H. P., 1987: Das digitale Orthophoto - Basis fuer neue Moeglichkeiten rechnergestuetzter Kartographie, KN, 4/87; 134-140.

Fras, Z., 1990: Digitalizacija katastarskih planova skanerom. Geodetski list, Zagreb, letnik 45 , št. 1-3; 35-50.

Fras, Z. \& Kosmatin-Fras, M. \& Vugrin, M., 1990: Razvojni projekt ORTO. posebna publikacija Geodetskega zavoda RS, 16 strani, Ljubljana.

Fras, Z. \& Gvozdanović, T., 1991: Digitalizacija katastrskih načrtov - programska oprema za digitalizacijo. Geodetski vestnik, letnik 35, št. 3; 145-150.

Fras, Z., 1992: Enoslikovna fotogrametrija $v$ dobi analitične in digitalne fotogrametrije. magistrska naloga, FAGG-KFK.

Fras, Z., 1992: Bližnjeslikovna fotogrametrija - stanje in trendi.Študij ob nalogi na tretji stopnji, FAGG - KFK.

Fras, Z., 1992: Digitalni ortofot - osnovni informacijski sloj v GIS. referat na 25. geodetskem dnevu, Rogaška Slatina 23.-24.10.92.

Gvozdanović, T., 1990: Automatizovano editiranje vektorske slike katastrskog nacrta. Geodetski list, Zagreb, letnik 45, št. 4-6; 35-50.

Kosmatin-Fras, M., 1989: Of-line izdelava digitalnega ortofota v praksi, Ljubljana. GV, 3/33; 133-141.

Kosmatin-Fras, M., 1989: Tehnike digitalne obdelave posnetkov-orodje v rokah fotogrametra, Ljubljana. GV, 3/33; 122-132.

Kosmatin-Fras, M., 1989: Izdelava ortofotgrafij s tehniko digitalnega procesiranja slik na osebnem računalniku, The Software fair-Split, SC Gripe, 6.6.89 - 8.6.89. Zavod za informatiko i telekomunikacije, Split; 198-207.

Lovenjak, J., 1991: Fotogrametrični monorestitucijski sistem za aplikacije v arhitekturi. Diplomska naloga; št.405, FAGG, Univerza v Ljubljani.

Mueller, W., Sauleda, H., 1988: Orthophoto production in the new ContexMAPPER System. ISPRS, Commission 2, Kyoto, IAPRS, Vol. 27/B9; 224-232. 
Radwan, M.M., Makarovič, B., 1980: Digital Mono-plotting System Improvements and Tests. ITC Journal, 3/80; 511-533.

Rihtaršič, M. \& Fras, Z., 1991: Digitalni model reliefa 1 del: Teoretične osnove in uporaba DMR. Učbenik na oddelku za geodezijo, Katedra za fotogrametrijo in kartografijo, FAGG.

TeSelle, G., 1990: A Strawman Proposal For A National Digital Orthophotoquad Program, National Orthophotogrphy Forum, Maryland, USA, 1990.

Theriault, D. G., 1991: Improving the GIS Data Capture Situation: An Integrated Approach, Smallworld Systems Ltd., Cambridge, England; $1-8$.

Thorpe, J. A., 1991: A Practical Method for Handling Digital Orthophoto Files. AM/FM International 1991, San Diego, California. 